\title{
AN ANALYSIS OF PLANNED LIGHT INDUSTRY ZONING
}

A THEME of resistance to industrial neighbors by residential prop$A$ erty owners has characterized the brief history of zoning in the United States, ${ }^{1}$ despite the fact that a number of suburban municipalities have recognized the advisability of encouraging some types of industry to locate there as a means of promoting the economic, social, and even cultural welfare of the community. ${ }^{2}$

Before the advent of the industrial revolution in England, segregation of residence and industry was neither possible nor desirable, since craftsmen were engaged almost exclusively in "home-industry" trades. Yet, if a nuisance were created by their operation, equity could enjoin the offensive activity, thereby establishing the first industrial land-use control. ${ }^{3}$ Once the factory made its appearance, however, urban living changed. Industrial operations became noisy, dirty, and unsightly; houses of the factory workers were often crowded near the plant, and even the homes of the rich were affected by the "pall of progress.". As applied to such conditions, the law of nuisance was inadequate," although, for many years, no attempt was made to alleviate the situation created by the proximity of industry to private residential areas.

The United States experienced a similar undesirable development, although the problem was not so acute as in England, for a greater land area permitted adequate segregation of residential communities from the factories. That this result did not always obtain, however, is apparent from the severe overcrowding created in such areas as New

\footnotetext{
${ }^{2}$ I YoKLEY, ZoNiNG $\S \S 5-8$ (1953) contain a history of the law of zoning in the United States.

${ }^{2}$ See, e.g., Seiber v. Laawe, 33 N.J. Super. II5, I09 A.2d 470 (1954): Newark Milk Co. v. Township of Parsippany-Troy Hills; Law Division, Docket No. L-7381-55 P.W., Sup. Ct. Morris Co., N.J., May 22, 1957. In an article in New Jersey Municipalities, Feb. 1957, p. 6, Mr. Henry Fagin, Director of Planning, Regional Plan Association, Inc., stated that ". . . a good many towns, however, are finding that they do need some industrial ratables after all. Of course, they only want the plant that looks like Princeton University in mid-August."

3 For a comprehensive discussion of the application of the law of nuisance to land use control see GREEN, ZONING IN NORTH CAROLINA 6-21 (1952).

'Id. at I5. Mr. Green suggests that this is so because the law of nuisance has dealt with the worst sore spots in the community and it has been applied in a "sporadic, unplanned manner."
} 
York City, ${ }^{\mathrm{a}}$ where light and air were virtually excluded in the canyons of lower Manhattan, and factories, stores, and garages invaded formerly "high-class" residential areas. ${ }^{\circ}$

Consequently, New York, in 1916, through a building-zone resolution $^{7}$ which provided various land-use controls for certain restricted areas, was the first.city in the United States squarely to attack the problem of industrial miscreancy. The validity of the resolution was upheld in Lincoln Trust Co. v. Williams Building Corp., ${ }^{8}$. where, in a suit for specific performance of a contract for the sale of land, the Court of Appeals of New York held that the resolution was valid and did not create an encumbrance upon the land. The opinion emphasized that as the conduct of an individual may be regulated by the state, so, too, it is a proper exercise of the police power of the state to regulate an individual's use of his property.

Although the Lincoln Trust decision was a major advance in establishing the validity of zoning, the landmark case in the United States was Village of Euclid.v. Ambler Realty Co., wherein the Supreme Court of the United States upheld the validity of a comprehensive municipal zoning ordinance as a proper exercise of the police power of the community and declared that it was not unreasonable nor discriminatory as applied to the plaintiffs land..$^{10}$ - As a result of the decisions culminating in the Euclid.case, the general validity of comprehensive zoning was thus established.

Traditionally, however, industry has been regarded as the stepchild of zoning. When provision for industry is made in a zoning ordinance, it is usually relegated to the least desirable area of the municipality, a result dictated by the historic tendency to consider industry an un-

\footnotetext{
${ }^{5}$ See BASSETT, ZONING 20-25 (1936).

- Metzenaaum, Zoning 4 (1930).

The Resolution divided the city into three types of use districts, residence, business and unrestricted. Lincoln Trust Co. v. Williams Building Corporation, 229 N.Y. 313, 128 N.E. 209 (1920).

- Ibid.

${ }_{272}$ U.S. 365 (1926).

${ }^{10}$ In the Euclid ordinance, the city was divided into six use districts, three height districts and four area districts. Proponents of industrial expansion in the village opposed the ordinance on the ground that the majority of land area in the village could best be used for industrial purposes as two railroads ran through the town which was a suburb of Cleveland, thus providing ready transportation of industrial output to a major market area and distribution point. Mr. James Metzenbaum, attorney for the Village, describes the strategy employed in the: Supreme Court. of the United States in METZENAKUM, Zontng io8-122 (1930):-
} 
desirable neighbor. Some types of industrial development have, nevertheless, progressed beyond the offensive, noisy, factory stage, ${ }^{11}$ and, when located on spacious landscaped grounds and housed in small clusters of attractive buildings, may be considered compatible with residential areas. Many examples of such "campus industry" presently exist, ${ }^{12}$ and it is this type of industry which best lends itself to the needs of suburban communities in promotion of general municipal prosperity.

\section{SPECIAL-Industry AMENDMENTS}

Should a residential community deem it advisable to admit campus industry to an area zoned for residential use only, an amendment to the existant zoning ordinance is essential. An examination of the zoning enabling acts of seven representative states reveals five basic steps in adopting such an amendment: initiation, public hearing, procedure upon protest by landowners, passage by the town council, and publication. ${ }^{18}$

Usually an enabling act directs the town council to initiate all zoning ordinance amendments; ${ }^{14}$ however, in Illinois and California, a planning commission is designated as the initiating body, ${ }^{15}$ thus permitting

${ }^{22}$ An example of this type industry is the manufacture of precision electronic equipment which is usually manufactured in quiet inoffensive surroundings. Consequently, some ordinances linnit the industrial uses to the manufacture of small articles. Thus, publishing, research and testing of pharmaceutical products, manufacturing of precision electrical, electronic and optical equipment, engraving and light woodwork manufacturing only are permitted by one ordinance. BUILDING ZONE ORDINANCE OF TOWN OF YORKTOWN, N.Y. $§{ }_{5} A_{3}$ (1941) (amended 1957) on file in the Duke Law Library. However, the industrial use permitted should not be determined by the size of the article but by the effect the manufacturing processes have upon the surrounding area. Fagin, supra note 2, says "the processing of a tiny electronic part may be more of a nuisance in the neighborhood than the outfitting of a big yacht if the routine testing of that part causes all the nearby TV sets to rock and roll."

13 E.g., Fair Lawn Industrial Park in Fair Lawn, N.Y., Readers' Digest and International Business Machines Corp. in Westchester County, N.Y., B.F. Goodrich Co. in Akron, Ohio and Johnson and Johnson laboratory in New Jersey.

${ }^{18}$ Cal. Govt. COde $§ 65807$ (Supp. 1957), Conn. Gen. Stat. \& 375d (Supp. 1955), Fla. Stat. ANn. \$\$ 176.05-176.06 (Supp. 1956), Ill. Rev. Stat. c. 24, $\$ \S$ 73-78 (1955), MD. ANN. CODE art. 66B, \$\$ 4-5 (1951), N.Y. TOWN LAW \& 264 (Supp. 1957), PA. Stat. ANn. tit. 53, \$§ 39114-9 (1957). Cities of the "3d class" in Pennsylvania and "towns" in New York appear to be the governmental subdivision concerned with the instant problem.

${ }^{16}$ E.g., N.Y. Town LAW $\& 264$ (Supp. 1957). "The town board shall provide for the manner in which such regulations and restrictions and the boundaries of such districts shall be determined, established . . . and from time to time amended, supplemented or changed."

${ }^{28}$ Ill. Rev. Stat. c. 24, \& 532 (1955), CAz. Govt. Code ANN. § 65603 (Supp. 1957). "Every plan commission ... has the power: ... (3) To prepare and recom- 
an administrative agency to expedite the processing of an amendment by reviewing every proposal and eliminating all but the most meritorious, and, at the same time, relieving the town council of a time-consuming duty. It is arguable that such a procedure tends to minimize the town council's role by making it a rubber stamp for the planning commission, but this contention would appear to be substantially without merit, since the planning commission is ostensibly better-qualified to consider zoning amendments, and the town council is thereby freed to consider other, perhaps more pressing, public matters.

The enabling acts consistently require a public hearing at which an opportunity for a full and open discussion of the amendment must be provided. ${ }^{16}$ Moreover, the public must be notified of the time and place of the meeting, usually by publication, ${ }^{17}$ and the amendment must be set forth in full in the notice. ${ }^{18}$ In Connecticut, the statute requires that the amendatory regulation be filed with the town clerk for public inspection at least ten days before public hearing. ${ }^{19}$ California adopts still another method of notification, providing that if an area is to be changed, the notice of the public hearing must be mailed to owners of property on the assessment rolls whose property is located within the area or within three hundred feet of the area in question. ${ }^{20}$ In some other states, notice to interested state agencies may also be required.

mend to the corporate authorities from time to time, plans for specific improvements..." Ir.. REv. STAT. c. 24, §.53-2 (1955), "The planning commission or the planning department may prepare and submit to the legislative body . . such . . . measures as may be required to insure the execution of the master or general plan."

${ }_{10}$ See, Fla. Stat. ANN. \& 176.05 (Supp. 1956). "No such regulation, restriction, or boundary shall become effective until after a public hearing in relation thereto, at which parties in interest and citizens shall have an opportunity to be heard."

${ }^{17}$ See, PA. Strar. ANN. tit. 53, §39114 (1957).

${ }^{18}$ CONN. GEN. STAT. $\$ 375 d$ (Supp. 1955) provides ". . . a copy of such proposed regulation or boundary shall be filed in the office of the town, city or borough clerk, as the case may be, in such municipality for public inspection at least ten days before such hearing, and anay be published in full in [a news] paper [of general circulation]." In Hutchinson v. Board of Zoning Appeals of the Town of Stratford, I38 Conn. 247, 83 A.2d 201 (195I), the published notice did not set out in full the changes to be made but merely stated that use changes would be made within a certain district. The ordinance was declared a nullity when the boundaries of the district were changed without notice. See also, Alabama Alcoholic Beverage Control Board v. City of Birmingham, 253 Ala. 392,44 So.2d 593 (1950).

15 CONN. GEN. STAr. \& 375d (Supp. 1955). In Ribeiro v. Town of Andover, 19 Conn. Sup. 438, II6 A.2d 769 (I955), noncompliance with the statute requiring filing the proposed amendment with the town clerk was held to render the enactment without operative effect.

${ }^{30}$ Cal. Govt. Code ANN. $\$ 65805$ (Supp. 1957). 
For example, Pennsylvania requires that the Department of Interior Affairs be notified, ${ }^{21}$ and New York provides that notice must be given to. the appropriate state park or parkway commission if a park or parkway is within five hundred feet of the area subject to change. ${ }^{22}$

If, at any time before passage of the ordinance, there is a written protest by a substantial number of property owners in the area affected, the statutes require a higher percentage of concurrence in the town council for passage of the amendment than would otherwise be required. For example, the Maryland enabling act provides that if there is a written protest by twenty per cent of the lot owners in the area to be changed or within one hundred feet in any direction of the area, a threequarters vote of the town council is necessary for passage. ${ }^{23}$

Finally, most-states compel publication of the amendment for a specified period in a newspaper of general circulation after it has been passed by the town council, ${ }^{24}$ while other states require posting in the "market place"2s or on a sign board maintained by the town clerk. ${ }^{20}$ Some few. states make no provision whatsoever for the publication of the ordinance.

The validity of such an amendment is subject to a variety of. challenges by the opponents of industrial inundation of residential. zones. ${ }^{27}$ These may logically be subsumed within three general cate-

${ }^{21}$ Pa. Stat. AnN. tit. 53, § 36014 (1957).

"2. N.Y. Town LAW \$ 264 (Supp. 1957).

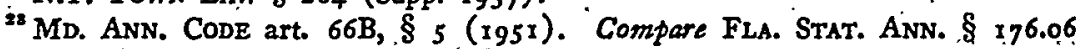
(Supp. 1956), providing for protest by landowners within 500 feet of the area to be changed, with MD: ANN. CODE art. 66B, \& 5 (r95r), providing for protest by landowners within 100 feet of the area to be changed. It is conceivable that allowing protest by landowners situated as far as 500 feet from the area to be changed might give a more representative aura to an amendment passed thereafter; however, allowing so large an area of landowners to protest may possibly have the effect of thwarting desirable amendatory enactments because of the greater possibility of an increase in the number of votes of the town council required to pass the amendment.

"ILL. REV. STAT. c. $24, \S$ 10-3 (1955).

${ }^{28}$ FLA. STAT. ANN. \& r65.20 (Supp. 1956).

${ }^{20}$ N.Y. Town LAW $\& 264$ (Supp. 1957).

"However, before an individual may challenge the validity. of an amendment establishing a special-industry district, he must show that.he has "standing" to maintain the action. Deligtisch v. Greenburgh, 135 N.Y.S.2d 220 (1954). It has been held that an individual has no standing unless he can show that a pecuniary loss will result. Bowen y. Hilder, 37 N.Y.S.2d 76. (r942); Bacernschnidt v. Standard Oil Company, 153 Md. 647, 139. Atl. 531 (1927). But see, Speakman v. Mayor and Council of North Plainfield, 8 N.J. 250, 84 A.2d 715 (1951); Wilcox v. Pittsburgh, 321 F.2.d 835 (3d Cir. 1941). See also Note, 9 BAYLOR L. REv. (1956) which concludes that one must live in close proxinity to the rezoned area in order to maintain the action.

"While a zoning ordinance or amendment thereto, being a legislative enactment, 
gories: first, that the amendment did not comply with the statutory procedure prescribed by the state zoning enabling act; ${ }^{28}$ second, that the amendment was an arbitrary and capricious exercise of the police power or was not designed to promote the health, safety, or welfare of the community, thus constituting a violation of the fourteenth amendment; ${ }^{20}$ and third, that the amendment resulted from an illegal delegation of the legislative power of the town board to an administrative agency ${ }^{30}$ such as a planning commission. ${ }^{31}$

A special-industry amendment which has been passed without strict procedural compliance with the zoning enabling act or similar statute will be held invalid, particularly when the deviation curtails the right of the public to a hearing upon the amendment or permits madequate notice of the hearing to be given, ${ }^{32}$ unless the reviewing court recog-

cannot, like a determination of a board of zoning appeals, be reviewed by certiorari or similar procedure, its validity can nevertheless be tested in an action for a declaratory judgment, or in some states, in an action for imjunctive relief." Zoning Bulletin, Regional Plan Association, Inc., No. 59 (1951).

13 I YOXLEY, ZONING \& 70 (1953).

" "The basis of the complaint, in either an action by an owner, the zoning of whose property has been raised (made more restrictive), or in an action by adjacent property owners where the zoning of an owner's property has been lowered (made less restrictive), would be as follows: the act of the legislative body is an improper and arbitrary exercise of the police power in that it does not promote public health, safety, or general welfare, [and] is discriminatory and therefore denies the equal protection of the laws to the plaintiffs." Zoning Bulletin, Regional Plan Association, Inc., No. 56 (June 1950).

${ }^{80}$ See DAvis, Administrative LAw $\$$ I2 (1951) which suggests that among the various factors affecting the constitutionality of a delegation of power are these: "Iack of procedural safeguards, the grant of substantial power to a petty political officer, absence of statutory guides or standards, and importance of the subject matter to parties affected."

"1he planning commission is an appointed body required to be established under most state zoning enabling acts and it functions primarily as an advisory group. The commission is usually empowered to adopt a master plan for the general development of the coinmunity, to make reports of an advisory nature to the town council and to initiate zoning ainendments. I YoRLEY, ZONING \& II4 (1953).

"2 The following cases were held invalid as constituting substantial deviation: Alabama Alcoholic Beverage Control Board v. City of Birmingham, $253^{\mathrm{Ala}} 402,44 \mathrm{So.2d}$ 593 (1950). (ordinance was not published before passage); City of Hollywood v. Rix, 52 So.2d 135 (Fla. I95I) (city ordinance enacted without a public hearing); Saks \& Co. v. City of Beverly Hills, ro7 Cal.App.2d 260, 237 P.2d 32 (x951) (incorrect publication of the notice of hearing). Ribeiro v. Town of Andover, Ig Conn. Sup. 438, 116 A.2d 769 (1955) (no publication in accordance with statute after passage of the ordinance); Hutchinson v. Board of Zoning Appeals of the Town of Stratford, $1_{38}$ Coim. 247, 83 A.2d 201 (I951) (notice did not state that zone boundaries would be changed but did inform the public of a use change from residence to light industrial district; the entire ordinance subsequently passed was a nullity). 
nizes an exception to this requirement. The Court of Appeals for the Eighth Circuit recognized such an exception in determining that the statutory provision was merely discretionary and not mandatory. ${ }^{39}$ Similarly, the validity of an amendment has been sustained, despite the lack of strict compliance, when the statutory deviation was technical and could produce no deleterious results. ${ }^{34}$

The challenge that a special-industry district amendment is an arbitrary or capricious exercise of the police power involves simply a determination of whether the amendment was reasonable under all the circumstances, since the only inference to be drawn from an allegation of arbitrary or capricious action in this context is that the amendment was adopted without consideration of all the relevant factors by the town

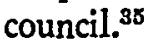

A characterization of unreasonable or arbitrary action is to be found in a charge of "spot zoning," which has been defined as the change of any lot or tract of land in the midst of an established residence district to any other less restricted district without adequate regard for location, need, topography, access, and effect on adjacent property. ${ }^{36}$ The challenge of spot zoning, however, may be overcome by a showing that the

Sikes v. Pierce, 212 Ga. 567, 94 S.E.2d 427 (1956) (where property rights are involved the absence of a hearing is a denial of due process). See also cases collected in Annot. 5I A.L.R.2d 263, 297.

Similarly vague language in defining boundaries of a district, or vagueness in any of its terms, will make an ordinance inoperative. See Taylor v. Moore, $303 \mathrm{~Pa} .469$, 154 Atl. 799 (x931); People v. Binzley, 146 Cal.App.2d 889, 303 P.2d 903 (1956).

Also, it has been held that the ordinance is invalid unless it is passed at a duly called and constituted meeting of the town council. Turk v. Richard, 47 So.2d 543 (Fla. 1950).

${ }^{38}$ De Lano v. City of Tulsa, 26 F.2d 640 (8th Cir. 1928), cert. denied, 278 U.S. 654 ( 1928 ).

st This theory has found judicial support in Louisiana and Kansas. Jonesboro $v$. Gentrey, 165 La. 1003, I 16 So. 488 (I928); City of Bluff City v. Western Light and Power Corp., 137 Kan. 169, I9 P.2d 478 (1933). See also 4 MCQuillan, Municipal Corporations $\$ 13.08$ (3d ed., 1949).

${ }^{85}$ It has been argued that the reasonableness of the amendment is the sole check upon zoning and that reasonableness is a vague term meaning anything which the mores of society, as recognized by the courts will accept. Haar, Foreword to Zoning in New England, 36 B.U.L. REv. 331 (1956).

'Zoning Bulletin, Regional Plan Association, Inc., No. 59, March 1951. The Regional Plan Association has defined spot zoning as "an amendment to the zoning ordinance and map to permit additional or less restrictive uses (downward rezoning) on one parcel of property while the surrounding neighborhood remains subject to the previous restriction." Zoning Bulletin, Regional Plan Association, Inc., No. 56, June 1950. 
amendment was enacted in accordance with a pre-existing valid comprehensive or master plan ${ }^{37}$ constituting a scheme for the orderly development of a town, so that maximum use may be obtained of the land area and natural resources within the town. ${ }^{38}$ Thus, if a planning commission or similar agency recommends certain zoning changes to the town council on the basis of a master plan and those changes are adopted, it has uniformly been held that the ordinance is valid. ${ }^{39}$

"A "coinprehensive plan" has been defined as a plan covering a wide expanse of territory and fulfilling pressing public needs for the forseeable future. Comment, Zoning in New England, 36 B.U.L. REv. 354,364 (1956). It has also been submitted that the existence of a comprehensive plan may be discerned from the public benefit resulting from zoning, i.e. the uniqueness of the area and the generality or specificity with which the statute describes the area affected. Note, Zoning-The NonConforming Use and Spot Zoning, I BufFalo L. REv. 286 (1952). Such analysis of the term may lead to confusion; however, Haar has lucidly placed the whole probleun in a clearer perspective. "This general plan or comprehensive plan, with which the amendinent must conform, is many things to many courts. It may be the basic ordinance itself . . . or it may be nothing more than a general feeling of fairness and rationality." Haar, "In Accordarice With a Comprehensioe Plan," 68 HARv. L. REv. II 54 (1955). Indeed, the cases make no attempt to define the necessary ingredients of a comprehensive plan. Such a plan is to be distinguished, however, from a "master plan" which is a document showing, inter alia, a survey of the present conditions of the area, a program for the correction of undesirable conditions, an estimate of the future growth of the town and an indication of long term goals. Haar contends that "master plan," "comprehensive plan," "city plan," and "general plan" have no functional distinction. See Haar, The Master Plan: An Impermanent Constitution, 20 LAW AND CONTEMP. PROB. 353 (1955). However, it seems undeniable that some distinction is apparent as well as desirable.

" See Jones v. Zoning Board of Adjustment of Long Beach, 32 N.J. Super. 395, 108 A.2d 498 (1954), where a section of a 1000 acre tract was rezoned froin "Residential" to "Business." The rezoning was resisted on the grounds that the area was primarily one of natural beauty and contamed only 35 hoines and that there were ample shopping facilities accessible to all the houneowners of the area and therefore the rezoning was unreasonable and should be declared invalid. The court upheld the ordinance as a proper exercise of the power to zone when the council rezoned the area to provide an accessible shopping center for the entire town. The zoning was held to conform to the requirements of N.J. REv. STAT. $\$ 40: 55-32$ (1940) providing that all zoning regulations are to be established in accordance with a coinprehensive plan and designed to: "lessen congestion in the streets; secure safety from fire, panic and other dangers; promote health, morals or the general welfare; ... prevent the overcrowding of land and buildings; avoid undue concentration of population." The statute also provided that the town legislative body consider "the character of the district and its peculiar suitability for particular uses. . . " [Emphasis supplied.]

"See Rodgers v. Village of Tarrytown, 302 N.Y. I15, 96 N.E.2d 731 (1951). In this case, a leading spot zoning decision, the plaintiff sought a declaratory judgment to declare invalid an ordinance which rezoned a small parcel of a large singe-family residential area to permit garden apartments in the rezoned area. The court held, inter alia, that the ordinance was enacted in accordance with a comprehensive plan 
Moreover, there has been a demonstrated tendency by the courts to look behind the comprehensive plan to the economic and social utility to be served when determining the validity of an amendment. A leading New York decision, Nappi v. LaGuardia, ${ }^{40}$ involved a specialindustry amendment based on the New York City zoning resolution, which provided for the following uses in a residential area:

Landscaped administrative offices, industrial laboratory projects and light industrial plants consistent with and designed to promote and benefit the value and use of property in residence districts. ....11

Certain residents of the rezoned area brought an action to have the amendment declared invalid, alleging that the industrial uses permitted constituted spot zoning and consequently a capricious exercise of legislative discretion. The court held that the amendment was not spot zoning, as it was part of a general scheme, and stated that since Sylvania Electric Corporation, the industry involved, intended to use the property for a research plant, it could only be located in a restricted residential area because the character of the work to be done required serenity and quiet..2 Quite clearly, the court was looking behind the

and that "spot zoning' is the very antithesis of planned zoning. If therefore an ordinance is enacted in accordance with a comprehensive zoning plan, it is not spot zoning,' even though it ( 1 ) singles out and affects but one small plot ... or (2) creates in the center of a large zone small areas or districts devoted to a different use." Id. at 735. See also Fieldston Garden Apartments v. City of New York, 145 N.Y.S.2d 907 (N.Y. Sup. 1955) (upholding as being in accordance with a comprehensive plan an ordinance rezoning to a retailed zone a small area located within a large residential district); Offutt v. Board of Zoning Appeals of Baltimore County, 204 Md. 55 1, 105 A.2d 219 (1954) (upholding the rezoning of an area from Residential to Light Industrial since the amendment was enacted in accordance with a comprehensive zoning ordinance); Schmidt v. Philadelphia Zoning Board of Adjustment, 382 Pa. 521, 114 A.2d 902 (1955) (rezoming a section from, "Residential" to. "Industrial" was held valid). In none of the above cases was it possible to deduce what constituted a comprehensive plan. In Offutt v. Board of Zoning Appeals of Baltimore County, supria, it was apparently held that a comprehensive zoning ordinance served the same purpose as a comprehensive plan.

${ }^{10}{ }_{184}$ Misc. 775,54 N.Y.S.2d.722 (1944). Aff'd 269 App. Div. 693 (1954).

${ }^{41}$ New York City Zoning Resolution, art. II, $\S_{3}$ (10), amended. Although the amendment allows industrial uses in a residential area, there are stringent requirements which inust be inet by an industry taking advantage of this section. First, the plaut buildings must not cover more than 25 per cent of a tract no smaller than so acres. Second, no building may exceed a height of 50 feet. Third, the architecture of the buildings must be consistent with the surrounding residential areas. Fourth, any part of the tract not occupied by buildings must be landscaped as a park area and be opened to the public.

“Nappi v. LaGuardia, 184 Misc. 775, 785, 54 N.Y.S.2d 722, 728 (1944). 
general plan to determine that the rezoning ordinance was a reasonable exercise of municipal power.

Where a campus-industry amendment has been enacted in the absence of a comprehensive plan or pursuant to a master plan which does not contemplate such action, a court is similarly faced with the necessity of a factual determination of the reasonableness of an amendment which allows industry to exist adjacent to a residential area. This was the case in Campbell v. Borough of Hillsdale, ${ }^{43}$ where a one-acre lot was rezoned from a residential area to a light industrial area to permit the operation of a candy plant. The rezoning was declared invalid after the court had examined all the surrounding circumstances, foremost among which appeared to be the fact that the rezoning would benefit only one individual. ${ }^{44}$

Since most courts will consider the over-all effect of an industrial use upon surrounding property, a campus-industry amendment to the zoning ordinance is quite often open to a charge of having created a nuisance, which, if true, is the essence of capricious action. Careful draftsmanship and proper planning of the amendment can, however, preclude creation of an industrial nuisance, the most obvious examples of which are the emission of dust, noise, smoke, and odors. Rather than prohibit altogether certain potentially offensive industries, ${ }^{45}$ however, "performance standard" zoning has been adopted, which, by special amendment, allows admission of certain types of industry complying with specific restrictions on emission of noxious odors, noise, and dirt. ${ }^{46}$

4212 N.J. Super. 182,79 A.2d 321 (195I). Other cases holding an ordinance invalid for failure to conform to a coinprehensive plan are these: N. T. Hegeman Co. v. Mayor and Council of Borough of River Edge, 6 N.J. Super. 495, 60 A.2d 767 (x949) (ordinance establishing set back lines held invalid); Cassel v. Mayor and City Council of Baltimore, 195 Md. 348, 73 A.2d 486 (x950) (creation of commercial district in residential area held invalid); Speakman v. Mayor and Councif of North Plainfield, 8 N.J. 250, 84 A.2d 715 (x951) (creation of Modified Commercial Zone in a preexisting Resideutial Zone held invalid).

"'This amendment was invalidated notwithstanding a referendum of the 1300 residents of the community of which 1100 had voted in favor of the amendment. It seems, then, that a judicial determination that the aniendment was not enacted in accordance with a comprehensive plan obviates the announced desires of a majority of the community.

${ }^{45}$ This rigid method is applied in the Building Zone Ordinance of THE Towin OF. RAMAPO, NEW YoRx, p. 14-15 (amended 1953), which lists 52 specific types of industrial operations fron1 acetylene gas manufacturing to yeast manufacturing which are excluded. The ordimance then provides for the exclusion of "any other trade or use that is noxious or offensive by reason of the emission of odor, dust, smoke, gas or noișe.".

"For example, the BuILDING ZONe "ORDinance of THE TOWN of Yorktown, 
Usually, such an ordinance prohibits those industries which emit offensive amounts of noise and substances discernable at the property line. Fulton County, Georgia, for example, provides that noise suppression devices must be used where noise resulting from normal operations may be heard more than one hundred-fifty feet beyond the property lines. ${ }^{47}$

Another condition quite often considered a nuisance is industry's capacity to generate heavy traffic, which must be excluded from residential areas if optimal living standards are to be maintained. ${ }^{48}$ That such a result is capable of attainment has been demonstrated at the Johnson and Johnson laboratory in Newark, New Jersey, and at the B. F. Goodrich laboratory in Akron, Ohio, ${ }^{48}$ where elimination of traffic congestion in the residential area was achieved by requirements of off-street parking facilities and a schedule limitation to certain hours for truck transportation. Similarly, selective zoning of areas for special industry districts accessible to major existing roads would alleviate traffic generation in the residential area. ${ }^{50}$. In Parson $v$. Toron of

N.Y. 85 (amended 1957) provides for the establishment of a Planned Light Industry District. This ordinance enumerates not the prohibited uses but those uses permitted. In addition it provides that other industry will be acceptable if it can comply with fixed standards regarding offensive enissions. Performance standard zoning is commented upon generally by Polk, Performance Zoning for Industry, 38 Public ManaceMENT 79, 1956, where it is defined as fixed, objective criteria designed to limit the affect of an industrial operation upon adjacent uses and upon the entire community. Municipal Administration, Associated Institutes of Government of Pennsyleania Universities (Dec. 1952), suggests that performance zoning, although a new concept, is ripe for greater application due to technological advances which have provided noise deadening techniques and installations preventing the emission of recognizable offensive amounts of smoke odors. The present application of performance zoning is also urged by one of the outstanding community planning consulting firms, Frederick P. Clark \& Associates. See Memorandum, Revised Draft of Proposed Planned Light Industrial District Regulations by M. S. Emanuel of Frederick P. Clark \& Associates dated June 22, 1957, on file in Duke Law Library.

"Site Regulations for Fulton Industrial District, Fulton Co., Georgia (undated) on file in the Duke Law Library. See also, letter from Mr. Harold Sheats, County Attorney, Fulton Co., Georgia, to the Dure Law Journal, March 8, 1958 which states that the general zoning "law of Fulton County ... prohibits in general those uses which may be obnoxious or offensive by reason of emission of odor, dust, smoke, gas or noise or vibration.' Art. XVI, Sec. 2, Par. 33."

${ }^{4}$ Fonoroff, The Relationship of Zoning to Traffic-Generators, 20 LAW AND CONTEMP. PROB. 238 (2955). The article contains an exhaustive discussion of the impact of vehicular traffic on various use districts, especially residential areas.

"Fonoroff, op. cit. suppra at 245.

${ }^{80}$ Fonoroff, op. cit. supra at 243 . The article supports the requirements for offstreet parking because it would tend to remove obstacles to traffic activity. In addi- 
Wethersfield, , $^{51}$ the court considered the proximity to a major highway of the rezoned land to be an "important factor" in sustaining the amendment. Furthermore, a Massachusetts court upheld an amendment when it was apparent that the city council had made the best possible use of land along a main highway when the district was rezoned from a residential area to one for special industry. ${ }^{52}$

A further objection to special-industry zoning arises from a fear that industrial neighbors will depreciate residential property values, and as a result, the amendment is challenged as being arbitrary and capricious. That such an argument is regarded as being without merit is illustrated by the case of Robinson v. City of Los Angeles, ${ }^{53}$ where the city had rezoned 785 acres of vacant land from an agricultural zone to a light industry area. The court stated that the ordinance was not invalid even though homes situated as far as a quarter of a mile away would depreciate in value, since damage caused by the proper exercise of the police power is "merely one of the prices an individual must pay as a member of society."354 Practically, however, it seems clear that surrounding residential land need not depreciate if proper restrictions are placed upon the industrial use. ${ }^{55}$

Aside from assertions that it constitutes an improper exercise of the police power, however, an amendment for special industry may be challenged on the ground that such action is beyond the scope of local

tion, however, in a residential area it seems possible that a prime factor influencing such requirement would be to assure an atmosphere of serenity and quiet.

61 135 Conn. 24, 6o A.2d $77 x$ (1948).

sx Shannon v. Building Inspector of Woburn, 328 Mass. 633, 636, 105 N.E.2d 192, 194 (1952), wherein the court states: "The areas zoned for residential and manufacturing uses before the amendment were not of a character to attract large modern manufacturing plants. The city council could reasonably conclude that rezoning the areas adjacent to the new circumferential highway for manufacturing and business purposes would attract to Woburn desirable manufacturing and business establishments which otherwise would not locate there. ..."

${ }_{146}$ Cal.App.2d 810, 304 P.2d 814 (1956). See also, other cases in which confiscation had been alleged and in which it was held there had been valid exercise of legislative power. Williams v. Village of Schiller Park, g Ill.2d 596, 138 N.E.2d 500 (1956) (depreciation of nearby property); Rams-Head Co. v. City of Des Plains, 9 Ill.2d 326, 137 N.E.2d 500 (1956) ( $\$ 32,000$ market loss); Pondfield Road Company v. Village of Bronxville, I A.D.2d 897, 150 N.Y.S.2d 910 (1956) (limitation of usable floor area).

s6 Robinson v. City of Los Angeles, supra note 53 at 816 . Also the opinion of one text is that although the police power is subject to various limitations its use in zoning is not limited by mere financial loss. I YoxLEY, ZoNing § 35 (1953).

${ }^{55}$ See material from the files of the Regional Plan Ass'n., Inc., N.Y., on file in the Duke Law Library which points out that planned light industry districts exist in 
legislative authority-that the amendment has no relation to the public health, safety, or welfare. Thus, it has been held that zoning based upon aesthetic or financial considerations is not encompassed within the police power ${ }^{66}$ and is, therefore, void. ${ }^{67}$ The Supreme Court of the United States, however, in Berman v. Parker, ${ }^{68}$ announced that the "traditional applications" of the police power-public safety, health, and welfare-are not limitations upon its valid exercise, but are rather illustrations of a broader power which might properly include "aesthetic

areas surrounded by $\$ 40,000-\$ 50,000$ homes. An example would be Fair Lawn Industrial Park in Fair Lawn, N.J.

${ }^{80}$ The rule that zoning based an aesthetics is invalid is illustrated by City of West Palm Beach v. State, $158 \mathrm{Fla} .863,30$ So.2d 491 (1947) where the city atteinpted to require that every new building should substantially equal the adjacent.building in appearance. The ordinance was held to be void as having no relation to the health, safety or morals of the public. For the view that economic considerations are not a proper basis for zoning see Ingersoll v. Village of South Orange, 3 N.J. Misc. 335, 128 Atl. 393 (Sup. Ct. 1925) where the city prohibited apartment houses in any zone because the city could not afford proper fire fighting equipment.

For many years writers have urged the courts to extricate themselves from existing confusion over the role of aesthetics in community land programs. See Dukeminier, Zoning for Aesthetic Objectioes: A Reappraisal, 20 LaW AND CONTEMP. ProB. 218 (1955) where it is suggested that in some instances zoning for aesthetic purposes is valid and when that is the case the courts should broaden the definition of the proper exercise of the police power to include aesthetics rather than twisting each case to fit within the traditional spheres of proper exercise of the police power such as health, safety. or morals. But see Sayre, A esthetics and Property Values: Does Zoning Promote the Public Welfare?, 35 A.B.A.J. 471 (1949), which postulates that property value protection is a valid exercise of the police power; that aesthetic zoning protects property values, thus aesthctic zoning is valid.

${ }^{87}$ The following cases have declared ordinances invalid as zoning for aesthetic purposes: Women's Kansas City St. Andrew Society v. Kansas City, 58 F.2d 593 (1932) (zoning old ladies home out of residential area); Hitchman v. Oakland Township; 329 Mich. 331, 45 N.W.2d 306 (1951) (imposition of minimum floor area for houses held invalid); Trust Company of Chicago v. City of Chicago, 408 Ill. 91, 96 N.E.2d 499 (195I), (changing half block from apartment to residential use under the circumstances invalid).

"In zoning cases [as these] no matter what the real problems are, it is generally argued that the regulations under attack were really concerned with the public health and safety. Moreover, it is customary also to invoke the general welfare' in a way which seems to assume that this is something definite and meaningful, and also something quite different from health and safety. It is rare that the particular problenis affecting health, safety or other aspects of welfare are spelled out, analyzed, and evaluated. There is then no reason to be surprised that the resulting court opinions tend to proceed on a remarkably low intellectual level." Williams, Planning Law and Democratic Liqing, 20 LAW AND CONTEMP. PROB. 317, 318 (1955).

348 U.S. 26 (1954). This case involved the District of Columbia Redevelopmerit Act of 1945, the purpose of which was to employ the government's power of eminent domain to clear slum areas of "blighted" housing. The plaintiff objected to the de- 
and spiritual values." Consequently, when faced with a requirement that buildings and grounds conform to a standard compatible with the surrounding residential area, industry will have little success in pressing the argument that aesthetic zoning is ultra vires. Such a requirement could have the effect of lessening the impact of industry upon adjacent property, by providing for "buffer zones" of wooded or shrubbed areas to be established between the industry site and adjacent residential property ${ }^{50}$ and that the plant buildings substantially harmonize with the predominant architectural style of the area. ${ }^{60}$ Similarly, a requirement that buildings should be set back from the property line and limited to an area of a designated percentage of the site would further the desired result, as would restrictions which limit the height of the buildings to some specific standard. ${ }^{\text {.1 }}$

Financial considerations were originally held improper criteria upon which to base a special-industry zoning amendment, ${ }^{62}$ but this rule seems recently to have been somewhat relaxed in line with the more liberal approach to rezoning for industry. Illustrative is Seiber $v$.

struction of his property, a department store, which he contended was not blighted housing, and thus the destruction would be violative of due process as the taking of his property was not for the purpose of advancing the public health, safety or morals. The court held the act valid, and it said that "public safety, health, morality, peace and quiet, law and order . . . merely illustrate the scope of the police power and do not delimit it." 348 U.S. 26, 32. Some writers have heralded this statement as the Supreme Court's recognition of the validity of zoning for aesthetic purposes. Comment, 39 Mare. L. Rev. 135 (1955); Johnson, Constiutional Law and Community Planning, 20.LAW AND CONTEMP. PROB. 199, 207 (1955); Rodda, The Accomplishment of Aesthetic Purposes Under the Police Power, 27 So. CallF. L. REv. 149 (1954); Regional Plan Association Inc. Bulletin 86, Zoning Advances in the New Jersey-New York-Connecticut Metropolitan Area.

${ }^{88}$ See Memorandum, Frederick P. Clark \& Associates, Planned Light Industry Zones, June 27,1957 , wherein the use of buffer zones is urged when industrial property is adjacent to residential areas.

${ }^{\circ 0}$ Ibid.

"1 Rhode Island Development Council, Local Planning Bulletin 9, March 15, 1957, which urges that "when a.new industrial use comes into being, protection can and should be provided for nearby residential property... . The principal provisions which have been used for some time in better zoning texts [include] the following: (a) a .reguirement that yards be provided and building heights limited on iudustrial property adjacent to residential areas; (b) for industrial uses that tend to be unsightly, such as the outdoor storage of materials, there should be provision for fencing or natural screening between the industrial use and the residential area."

${ }^{62}$ See Ingersoll v. Village of South Orange, 3 N.J. Misc. 335, 228 Atl. 393 (Sup. Ct. 1925) discussed at note 56 supra; Springfield Township v. Bensley, 19 N.J. Super. I47, 88 A.2d 271 (Ch. 1952) wherein it was held that the court would not consider the financial evidence advauced and thereby uphold a zoning ordinance which otherwise 
Laawe, ${ }^{63}$ where the court upheld the validity of an amendment permitting "laboratory projects" to enter previously residential areas, noting that since the town had exceeded its legal borrowing power, additional revenue provided by laboratory projects would provide a solution to the current revenue problem. Thus, in the light of the general tax benefits accruing to the township, the rezoning of a residential area was valid. Similarly, in the Township of Parsippany-Troy Hills, a special "floating zone" 64 was created, which could later be located in a particular area when the need for an industrial zone arose. The ordinance was based ostensibly upon the need to supplement current income with nonresidential tax ratables to defray the cost of necessary municipal services. In determining the validity of this ordinance, the court in Newark Milk Co. v. Parsippany-Troy Hills, ${ }^{\text {,b }}$ posed the following question and answer:

Is a zoning classification based upon such a purpose and intent a valid exercise of the police power? I think it is. Zoning ... may be invoked to serve the public health, morals and wellbeing. ${ }^{68}$

Thus, it is apparent that the validity of financial considerations in prompting a special industry amendment to the local zoning ordinance has gained judicial recognition.

had no relation to the public health, safety or morals. But see, Smith, Municipal Economy and Land Use Restrictions, 20 LAW AND CONTEMP. ProB. 481 (1955) wherein it is argued that the consideration of a municipality's financial burden does have a place in the development of a comprehensive zoning ordinance or amendment. Cf. Comment, Municipal Real Estate Taxation as an Instrument for Commumity Planning, 57 YALE L.J. 219 (1947).

${ }^{03} 33$ N.J. Super. 115, I18, 109 A.2d 470, 472 (1954). Pertinent portions of the amendatory ordinance are, " $\mathrm{x}$. In a Residence ' $\mathrm{A}$ ' or Residence ' $\mathrm{B}$ ' District, ... . [the following uses are permitted:] ... also, landscaped administrative offices, laboratories devoted to research, design and/or experimentation and processing and fabrication incidental thereto and appurtenant buildings consistent with and designed to promote and benefit the value and use of property in residence districts or in areas which are predominantly residential although partly lying in less restricted districts. . . ."

ot The floating zone is a district created in an ordinance but mapped in no particular spot: The ordinance provides all the standards and uses for the district which may be held in abeyance until the planning commission or town council decides that the zone should be applied to a particular tract of land. This type zoning has, apparently, not yet been tested in the courts. Regional Plan Association, Inc., Bulletin No. 86, Zoning Advances in the New Jersey-New York-Connecticut Metropolitan Area, p. 12, May 1956.

${ }^{85}$ Law Division Docket No. L-7381-55P.W., Sup. Ct., Morris Co., N.J., May 22, 1957.

${ }^{88} I d$. at 22. 
Finally, although the special-industry amendment as a whole may achieve judicial approbation, a particular section may be invalidated as an improper delegation of discretion to an administrative agency in supervising industrial site development. This point was raised in Newark Milk Co. v. Parsippany-Troy Hills, ${ }^{67}$ where the town council delegated to the planning commission the power to pass upon the appropriateness and design of the site plan in relation to the character of the neighborhood. The court held that such control by the planning commission would be interference with private land use for no valid purpose, and, moreover, that the planning commission could pass only upon such matters which were of a public interest, thus emasculating a provision essential for effective control of the industrial site use in the rezoned area. It is unfortunate that courts continue to accede to the delegation shibboleth, particularly when administrative co-ordination of industrial zoning with existing residential uses is essential in achieving the most beneficial and harmonious results.

An ordinance provision which delegates power to the planning commission to approve site plans is a fairly common phenomenon ${ }^{68}$ and should not incur adverse judicial criticism if an adequate set of standards or a statement of policy is provided whereby the commission may determine whether or not the site plan is harmonious with the surrounding residential area. ${ }^{69}$ In one special-industry ordinance, the criteria adduced for the benefit of the commission in determining whether the site blends properly with the surrounding area include the location of the buildings on the property, the uses to be established

${ }^{67}$ Id. at 27.

${ }^{88}$ See American Society of Planning Officials, Architectural Control-A Collection of References io, and Summaries of, Articles Dealing with Architectural Control; Excerpts from Zoning Ordinances (undated). An example of such delegated power is contained in the Pasco, Washington ordinance which provides that telephone exchanges and similar public utility uses may exist in a residential area by special permit of the planning commission provided that such buildings conform to and harmonize with the surrounding buildings as to architecture, setback and landscaping.

${ }^{\circ} \mathrm{Cf}$. Davis Administrative Law $\S$ I7 (1951) wherein it is noted that many state courts are quite lenient toward sweeping delegation when such grants achieve socially desirable ends and some courts have even gone so far as to imply standards which, in fact, were not stated in the legislation. Perhaps the following delegatory provision may be regarded as providing the proper standards: ". . The Planning Board shall consider the location of such business, industrial and office buildings and related uses with respect to the topography of the lot, with the objective of securing a maximum harmony of such buildings and uses with the surrounding landscape and existing uses. BuILding ZoNe Ordinance, TOWN OF YorkTOWN, N.Y. \& 5 AI (194I) (amended 1957). 
in connection with the topography of the lot, the use of buffer strips, and the height and architecture of the buildings. ${ }^{70}$ By including these criteria, the ordinance appears to establish sufficient minimum standards to protect neighboring property from most potential "sight nuisances." An even more workable ordinance is that of the City of Santa Barbara, California, which provides that the planning commission may pass upon site plans showing the "proposed landscape or treatment of the grounds around the buildings... in keeping with the character of the neighborhood."'71

The problem of delegation of legislative, power is frequently encountered when the ordinance grants an agency the power to declare a "variance." In In this situation, it has been held that the delegation is valid if accompanied by a standard sufficiently precise to guide the agency in its determination. ${ }^{73}$ By analogy, it would seem that delegation of power to the planning commission should be subject to no greater limitation.

\section{ConcLusion}

Admission of a carefully-selected and well-planned light industry to residential communities will undoubtedly, in many instances, prove mutually beneficial. Virtually without exception, industry. would enjoy lower tax rates, better working conditions for its employees, lower operating costs, and the aesthetic values and benefits inherent in the serenity and quiet of a residential background. Concomitantly, the municipality would benefit from an enlarged tax base, an increase in the volume of local business, a possible solution of local unemployment problems $^{74}$ and a diversification of social strata which would arguably lead to the development of an indigenous cultural characteristic.

\footnotetext{
${ }^{70}$ Building Zone Ordinance, Town of Yorktown, N.Y., § 5AI (1941) (amended 1957).

${ }^{71}$ Building Zone Ordinance No. 47, San Pablo, Calif, $\$ 4.6$ (1950).

${ }^{72} \mathrm{~A}$ variance is a special form of relief granting to the landowner permission not to use his land in conformity with the ordinance when compliance would result in unnecessary hardship. RHYNe, MUNIcIPAL LAW $\$ 8$ 32-16, 17 (1957). The facts which must exist before a variance is granted are: "( 1 ) the land in question cannot yield a seasonable return if used only for a purpose allowed in that zone; $(2)$ that the plight of the owner is due to unique circumstances and not to the general conditions in the neighborhood ....; and (3) that the use to be authorized by the variance will not alter the essential character of the locality." Otto.v. Steinhilber, 282 N.Y. 71, 76, 24 N.E.2d 851,853 (1939).

${ }^{78}$ Aloe v. Dassler, 278 App. Div. 975, 106 N.Y.S.2d 24 (1951); Crossroads Realty, Inc. v. Gilbert, 109 N.Y.S.zd 59 (Sup. Ct. 1951).

"Letter from Frederick P. Clark, community planning and development consultant, to the Duke Law Journal, Nov. 4, 1957, on file in the Duke Law Library.
} 